\title{
Society demands for the quality of education as a factor of modern education space forming
}

\author{
Svetlana V. Ivanova, ${ }^{1, *}$ and Oleg B. Ivanov ${ }^{2}$ \\ ${ }^{1}$ ISED RAE, director, 105062, Moscow, Russia \\ ${ }^{2}$ MSURE (MIIT), Corporate Management Department, 127994, Moscow, Russia
}

\begin{abstract}
The authors research the problems of increasing in modern conditions society demands for qualitative characteristics of education services. The quality of education is considered as one of the determining factors of forming educational space. The paper analyzes the influence of social and economic conditions inherent in the post-industrial era on forming and transforming of education space at the modern stage of society development, shows the ways to overcome emerging contradictions. The authors pay special attention to the significance of project approach in solving the problems of improving education quality.
\end{abstract}

Social and economic conditions always have a direct impact on education, its system, level and quality. This impact depends on specific features of the period of social-political and economic development of the state, region and consequently it is closely connected with the so-called "social demand", i.e. expectations of society. Society enters into post-industrial era, which is characterized by the increasing role of service sphere and its predominance over the industrial one, introduction of technological achievements into all spheres of life, development of information technologies and total computerization. Forefathers of the theory of post-industrial society D. Bell and E. Toffler determined the goals of the development of economy: minimization of commodity-money relations and their piecemeal replacement for universal (humanistic) values, transition of the leading role in the society from entrepreneurs to scientists, from corporations to universities [1]. Mankind has not entered into this stage completely yet, but it moves in this direction.

Thus, the post-industrial era makes higher demands for qualifications and personnel training, leads to the increase of the number of people engaged in intellectual labor, change of people's interest towards creative development and, therefore, change the society structure itself, increasing educational demands, rising demands for the quality in education. It is proved by comparative analysis of world-known ratings showing a) the presence of strong correlation of index of education with health care service and entrepreneurship and b) absence of dependence of index of education level and absolute or relative its funding (the number of people getting education of all levels does not depend on state and private expenditure for education) [2].
These special features of post-industrial society make us pay attention to the specificity of forming educational space as phenomenon to the fullest extent meeting social problems and efficiently providing the quality of education in the broadest sense of the term.

During consideration of social demand for education, a certain difficulty is the necessity of taking into account human nature dualism, opposition of individual and social, which was mentioned in various works of E. Durkheim. In particular, he notes that "this duality corresponds to our dual existence: its one aspect is purely individual and is inherent to our organism, while another has a social character and simply is a continuation of society $\langle\ldots\rangle$, society has got its own nature and therefore makes different demands than those which are implied by individual nature" [3].

It is known that considering the questions of the quality of education we should evaluate both economic and social conditions of forming educational space and conditions of the person's life. Only those conditions, which are to a certain extent favorable for the individual, can positively influence educational space. However, forming of the education space is also impossible only from subject-related position as it does not allow providing proper socio-economic conditions as well as solving the problems of state and society as a whole.

It is advisable to consider educational space within two aspects: as space having an objective world, i.e. the totality of various objects creating and filling this space, and as a place and an object of specific subjectrelated activity, including perception, action, and an influence upon the space from the subjects which are connected with it and affect it [4]. 
Let us consider social-economic conditions. The science of economics distinguishes there: the level of education, qualification and personnel's quality of education, living standard and lifestyle, the cultural level of population, the level of health care service, the level of unemployment, the real income of population, provision of population with material goods and services, labor conditions and labor safety, state regulation of social conditions (social protection of population, programs of poverty alleviation, state development of education, health care etc.); state fiscal policy and the policy of forming income of population (the minimum wage, scale of pension) [5].

Practically, each of these positions of socioeconomic conditions one way or another influences the quality of education level, forming educational space which, in its turn, affects these conditions changing them as well.

Comparing socio-economic conditions with the descriptions of modern (post-industrial) society, we can note their correlation in the positions we are interested in. The most essential demand of the epoch, which coincides with the first-rate social condition, is the quality of education.

Thus, the dependence of the quality of education on socio-economic conditions and the necessity to realize the corresponding society demand need monitoring of socio-economic conditions, timely and appropriate reaction for existent changes, prognostication and taking into account possible risks.

World economic crisis along with the further period showed that existing risk management systems, especially in the sphere of education, appeared not to meet modern challenges.

Let's single out several essential, in our opinion, factors of the influence of the environment on the socio-economic conditions of the society and, therefore, on educational space. In modern conditions they are, first of all, the factors connected with the influence of financial crisis and overcoming of its consequences:

- corporate collapses, financial difficulties, bankruptcies;

- continuation and aggravation of systemic economies' collapses, increasing of state debts, permanent fiscal imbalance;

- systemic imbalances of labor market, unemployment;

- unregulated migration, destabilizing not only labor market, but both social and criminal situation in a number of countries, including the EU;

- deterioration of economic situation of the population, exacerbation of social tensions;

- spread of corporate fraud and corruption;

- lack of efficient programs for strategic and operational risks management.

Breaking point of economy leads to the aggravation of social problems and, first of all, of unemployment which has become one of the main social-economic risks both for states and businesses and a personal tragedy for people who lost their jobs. It is necessary to note that the increasing number of unemployed is a global trend. According to experts of the International Labour Organization, the number of jobless people in the world exceeds 200 million. According to Eurostat, during last several years the level of unemployment in the Eurozone remains stable and seasonally adjusted it amounts to $12 \%$. This problem is much more pressing for the young people. In particular, the two thirds of Greek young people are jobless, while the unemployment rate runs up to $50 \%$ in Spain. The unemployment rate remains high for the other developed countries.

All this leads to the extremely austerity measures introduced by the EU and International Monetary Fund. Such countries as Greece, Spain, Portugal and Italy seriously reduced their budgets, having discharged hundred thousands of public sector workers and sharply cut salaries for the remaining employees, during last five years.

High poverty level of the population creates serious risks. Today this index in the EU (according to Eurostat) comes to 120 million of people. Also it is widely accepted that the so-called monetary poverty (this index shows the number of people whose real income is less than $60 \%$ of the average value in the country) creates a great threat to the well-being of the Europeans. There are about 90 million of such poor people in the EU.

The low living standards of the population, high unemployment rate besides the deterioration of the quality of life of the population involve a number of problems of social character:

- increase of crime;

- growing social tension of the population including developed countries;

- growing insecurity, depression, mental disorders, suicide etc.;

- decline in purchasing power of the population which leads to the aggravation of the problems of business and the further economy shrinking;

- increase of the pressure on public services due to the increase of the state support of jobless people;

- growing problem of the refugees up to the critical point in Europe during the last two years [6].

These factors mentioned above exert a direct influence on the situation in educational space where we can distinguish two opposite tendencies. On the one hand, the growing competition on the labor market leads to the growth of the need in a high-quality education, growth of expectations in the sphere of the improvement of the quality of education. On the other hand, the futility of obtaining sustainable employment as mass phenomenon causes fatigue, lack of concernment in getting educational services.

One more global risk of the modern world is the increase of fraud and corruption. It is necessary to state that this problem aggravates under the condition of economic instability. Criminal segment develops towards the next level, which involves heightened requirements to the quality of education as well. In the modern world the most "popular" economic crimes are: misappropriation of assets, bribing and corruption, forgery and concealment of accountancy data, tax 
evasion, money laundering and securities business using insider information, unfair competition and violation of intellectual property rights.

Crimes in the sphere of high technologies form a particular category of fraud (they relate to the category of the called "new" risks), need the highest professional level and, correspondingly, the quality of education. Among the total number of economic crimes in the sector of financial services about $40 \%$ of them are cyber-crimes. According to the European Commission, more than one million people are attacked by cyber-criminals every day in the world.

That is why it is important to note the fact that the development of highly intelligent crime needs high professional level and, consequently, appropriate demands for the quality of education [7].

All mentioned above brings us to the following conclusion. If the educational space is built up by subjects beyond the socio-cultural code, but based on the market foundation as providing services (what actually is one of the special features of post-industrial era), then it leads to the appearance of specific motivation of subjects and consumer attitude towards the objects of educational space and the subject activity inside it. This approach can hardly change the condition of the quality of education for the better. Here we see a profound contradiction of the modern post-industrial epoch, characterized by destructive tendencies, the condition is set which can be achieved by means accessible for the time and place, but not appropriate for achieving the quality of education.

Quite a specific position of Russia consists in the following: it is a federative state with living standards differing in economic status and socio-economic parameters in various regions. It allows different possibilities for achieving high quality education in regions. The Subjects of the Russian Federation vary in scientific and procedural support, resources, quality of training and the level of teachers' salary and many other characteristics affecting the quality of education. Regional educational spaces are different and, as a result, we note different rates of satisfaction of people by the quality of educational services.

It is obvious at present that people are preoccupied with technological processes caused by the aspiration for the development and deepening on information and communication technologies, forming special medium of communication with the help of telecommunication channels. Meanwhile the problem of the lack of direct, not mediated by communications technology dialog is not seen so critical. However, we cannot help noticing it during forming the educational process based upon information technologies, because the lack or minimization of dialogic communication, substitution of intersubjective relations by interaction with text changes drastically educational space, which affects changes of both its objects and subjects, as well as directly influences the quality of education. This problem is not so serious yet to make people discuss cutting down the use of information and communication technologies. It is impossible for the post-industrial age. What it involves is the perception of power of information technologies influence upon educational process, educational space and improving the quality of education.

One more essential condition involves geopolitical factors. Educational space can be looked at differently in a concrete region of the country, within the state as a whole and relative to the other countries. In our opinion, it is necessary to look at the educational space, basing upon the dichotomy perspective:

- as a factor of political and geopolitical stability/instability of the state and society;

- as a factor of the development of a successful integration and international cooperation or a factor, contributing to isolation, secrecy and the disruption of international relations;

- as a factor and condition of social development of a personality and society or, on the contrary, of negative destructive trends and unsuccessful personal destiny of people.

Integration into the world economy and world educational space can have both positive and negative results, due to specific geopolitics in the global world. It should be taken into account, while developing state and civil goals and objectives of improving the quality of education.

The demand of businesses on the formation of their own educational systems is one of the topical aspects of the problem for the development of educational space and solution of the problems of ensuring the quality of education. Today the majority of transnational corporations, as well as large Russian companies, establish their own systems of education and professional training including corporate universities. First of all, it is connected with the fact that contemporary university education has got its own disadvantages from the viewpoint of professional practitioners. Quite often knowledge which students acquire there turns out to have no necessary relation with real life. The system is overburdened with tutors who are unable to keep up with the times, one of the reasons being their isolation from real practice and demands from business. Their lectures are based only on bookish and often outdated knowledge and their methods of instruction do not further forming necessary competences. With a good general theoretical schooling, universities do not provide students with a set of special knowledge and competencies, necessary for efficient functioning of concrete business process (at the level of both a business unit and the whole business structure) and, as a result, their graduates are not adapted to the special needs of companies. It means that universities train a number of highly educated specialists with limited thinking skills who cannot implement practically acquired knowledge.

Despite standards, educational programs are quite variable and the demands for the quality of education of graduates from different universities are also not the same. Even in specialized universities the training is realized according to different educational programs and curricula. Programs are changed with the time, knowledge is updated and graduates of the same educational institution of different years may speak 
"different languages". Thereat in the conditions of tough competition at the labor market it is necessary to provide high quality training and retraining of personnel and continuing professional development.

Besides, knowledge becomes obsolete, and rapidly growing production needs more advanced and sometimes even other skills, greatly differing from those acquired at the university several years before. This causes the necessity of the establishment company's own system of continuing professional development of the whole personnel according to synchronized training programs which should be harmonized ideologically, methodologically, technologically and terminologically with special programs for various categories and levels of contingent.

We would like to accentuate one more time that intra-corporate professional development should be continuous, it should respond promptly to any challenges, changes of environment, market situation, international and national legislation, convey technological, organization, structural changes inside the company. Besides, the system of professional development should take into account world tendencies, best foreign practice and best domestic experience as well as attentive scrutinizing competitors' practices.

Considering the practice of building corporate system of professional development in a large company, let's take an example of JSC "Russian Railways" of the organization of such work in this area. The holding established such an integral system which involves all the categories of personnel, takes proper account of company's demands and its business units and includes all forms of education. At the same time, this system constantly develops and improves. This system of training and development, established by JSC "Russian Railways", features sustainability and allows effectively influencing the increase of economic and production indicators, changes the paradigm of managerial thinking and individual career of the staff members via forming an individual educational pathway based on introducing of the system of continuing education [8]. In fact, it means establishing corporate educational space based on project approach which meets holding's demands for the quality of education.

This is only the visible part of "iceberg" of the problems for educational space and the ways of their solution in relation to social conditions and influence of the post-industrial world. However, it shows the difficulties in forming educational space and meeting demands of the society for the quality of education. As far as we can see, there are difficulties both inside and outside of this space.

It is important to provide for the peculiarities of modern information society, globalizing world which entered into the post-modern epoch, special features of representation and interpretation for decisions in educational space and, certainly, economic conditions and social demands, while we evaluate and analyze the real situation, prospects and directions of the development of modern educational space ensuring the quality of education.

Highlighting favorable factors and risk factors made the question of the educational space design topical [7]. It is important to take into account the potential of project approach in education, practically still unused possibilities of the design of the educational space with regard to social-economic conditions and demands of modern society for the quality of education.

It appears that the design of educational space should be considered as managerial, but not the methodic task, i.e. to understand managerial design as the use of project activity in the management of the system of education. However, considering ideas of socio-cultural dimension of educational space [9], it is important to regard the design of educational space, first of all, in its qualitative, content-related aspect. Managerial project activity should be the activity of strategic nature, aimed not so much at institutional changes as at realization of cognitive approach towards educational space as the subject of design.

It is extremely important that the design of educational space is preceded by a large-scale analysis of educational situation (certainly, with regard to comprehensive evaluation of socio-economic status) based on sociological research, studies of qualitative features of the system of education from the viewpoints of regions and the country as a whole, in the light of the world integration processes, evaluation of expectations and the public mood. Only after it there comes the stage of setting goals and objectives of strategic nature and tactical meaning necessary during the certain period. The results are designed, planned and forecast on this very base, as well as the mechanisms of their achievement are worked out [10].

The design of educational space in whole allows minimizing the risks, determining the frustration points in the society, eliminating uncertainty in goals and realization of intensions, ensuring by that the quality of education. The design of educational space is, in our opinion, creation of integral, large-scale, coordinated plan (project) of activity of various structures for education management, which are obliged to solve modern problems to improve the quality of education.

\section{References}

1. D. Bell, Gryadushchee postindustrial'noe obshchestvo. (Akademiya, Moscow, 1999) [In Rus]

2. E.V. Bebenina, ETAP, 1 (2014)

3. E. Durkheim, Dualizm chelovecheskoi prirody $i$ ego sotsial'nye usloviya. Available online: URL http://sociologica.hse.ru/2013-12-2/92620498.html (accessed on: 14.09.2014) [In Rus]

4. S.V. Ivanova, Novoe v psikhologopedagogicheskikh issledovaniyakh, 6 (2013) [In Rus] 
5. Ekonomicheskii slovar'. Available online: URL http://abc.informbureau.com/ (accessed on: 25.02.2015) [In Rus]

6. The World Economic Forum. Global Risk Report 2015. Available online: URL http:/www.weforum.org/reports/global-risksreport-2015 (accessed on: 10.03.2015) [In Rus]

7. O.B. Ivanov, ETAP, 1 (2014) [In Rus]

8. O.B. Ivanov, Otechestvennaya i zarubezhnaya pedagogika, 3 (2015) [In Rus]

9. G.V. Sorina, V.S. Mes'kov, Tsennosti i smysly, 5 (2013) [In Rus]

10. S.V. Ivanova, Obrazovatel'noe prostranstvo kak ob'ekt proektirovaniya. (Pyatigorsk, PGLU, 2014) [In Rus] 